\title{
Rancang Bangun Sistem E-Commerce Marketplace Gypsum Berbasis Cloud Computing
}

\author{
I Gusti Ngurah Wira Dharma, I Made Sukarsa, Ni Putu Sutramiani \\ Jurusan Teknologi Informasi, Fakultas Teknik, Universitas Udayana \\ Jalan Raya Bukit Jimbaran, Kabupaten Badung, Bali \\ Telp: (0361) 701806 tlp/fax: (0631) 701954, 704845/(0361) \\ e-mail : ngurahwira27@gmail.com, sukarsa@unud.ac.id, sutramiani@unud.ac.id
}

\begin{abstract}
Abstrak
Perusahaan gypsum merupakan perusahaan yang bergerak dalam bidang penjualan, pendistribusian dan pemasangan platfon berbahan gypsum. Penjualan yang diterapkan masih terbilang konvensional sehingga kurang efektif untuk dijalankan karena banyaknya persaingan yang mengarah ke dunia digital, sehingga perlu dibuatkannya sistem e-commerce gypsum. Sistem e-commerce gypsum menerapkan sistem marketplace untuk dapat memberikan kemudahan konsumen dalam melakukan transaksi jual beli produk. Sistem e-commerce marketplace gypsum yang dibuat terdiri dari banyak penjual, serta penggunaan cloud computing untuk mempermudah pengaksesan data secara bersama-sama tanpa harus meng-instal aplikasi. Sistem e-commerce gypsum ini mengunakan API Google Maps untuk perhitungan jarak pengiriman produk, dan pembeli dapat melihat track record perusahaan dari rating setiap perusahaan. Rating diberikan oleh pembeli terhadap pelayanan (pengiriman barang, service, pemasangan) yang di berikan oleh perusahaan gypsum. Sistem informasi penjualan gypsum sudah berjalan dengan baik, dari aspek antarmuka maupun dari kesesuaian fitur. Pengujian kepada 20 responden memberikan penilaian sangat baik dan baik sebesar $80 \%$ dari aspek antarmuka, sedangkan dari aspek kesesuaian fitur responden memberikan penilaian sangat baik dan baik sebesar $86,26 \%$.
\end{abstract}

Kata Kunci: E-commerce, Cloud Computing, Marketplace, Google Maps.

\section{Abstract}

Gypsum company is a company engaged in the sale, distribution and installation of platforms. The applied sales are still conventional so it is less effective to run because of the many competition that leads to the digital world, so the gypsum sales information system needs to be made. The gypsum sales information system applies an e-commerce marketplace system to provide convenience to consumers in product sale and purchase transactions. The sales information system made consists of many sellers, as well as the use of cloud computing to make it easier to collect data together without having to install the application. This information system also uses google maps to calculate the distance of product shipments, and buyers can see the company's track record of the rating of each company. Ratings are given by buyers for services (goods delivery, service, installation) provided by gypsum companies. The gypsum sales information system has been running well, from the interface aspect as well as from the feature completeness. Tests on 20 respondents gave a very good and good rating of $80 \%$ from the aspect of the interface, while from the aspect of conformity the features of the respondents gave a very good and good rating of $86.26 \%$.

Keywords: Ecommerce, Cloud Computing, Marketplace, Google Maps.

\section{Pendahuluan}

Perusahan gypsum merupakan perusahan yang bergerak di bidang penjualan, pendistribusian dan pemasangan gypsum platfom. Gypsum merupakan jenis material yang biasanya digunakan untuk pemasangan platfon rumah, bentuk fleksibel, padat dan kering yang membuat gypsum mudah dalam proses pemasangan dan kontruksinya. Kegiatan jual beli perusahaan gypsum masih menggunakan proses konvensial seperti misalnya saat konsumen ingin memesan produk gypsum. Konsumen diharuskan memilih produk menggunakan buku

Rancang Bangun Sistem E-Commerce Marketplace Gypsum Berbasis Cloud Computing $\quad 37$ (I Gusti Ngurah Wira Dharma) 
katalog, dimana pembeli atau konsumen diperlihatkan buku katalog oleh pihak perusahaan, untuk memberikan informasi terkait produk dengan cara bertemu langsung antara pemilik perusahaan dengan konsumen. Kegiatan pemesanan yang masih terbilang sederhana sehingga banyak waktu yang dikeluarkan oleh pihak perusahaan maupun konsumen. Pemasaran yang masih dilakukan secara konvensional yaitu dari mulut ke mulut tentunya kurang efektif dilakukan di era globalisasi ini, melihat persaingan yang semakin banyak serta perkembangan teknologi yang semakin cepat. Pemasaran yang konvensional tentunya akan mempersulit konsumen untuk mendapatkan informasi tentang produk yang ditawarkan oleh perusahaan gypsum, maka dari itu perlu adanya media pemasaran online sehingga informasi dapat diakses dengan mudah.

Permasalahan yang dihadapi oleh perusahan gypsum tersebuat dapat diatasi dengan dibuatkannya sistem e-commerce (electronic commerce). Electronic commerce merupakan bagian dari e-business (electronic business) yang meliputi semua bentuk transaksi perdagangan barang atau jasa yang dilakukan secara elektronik [1]. Keberadaan e-commerce sangat penting di mililiki oleh perusahaan gypsum dimana dengan kehadiran e-commerce dapat mempermudah pemesanan dan pemasaran secara online. Pemesanan menggunakan e-commerce dapat memberikan kemudahan konsumen untuk memesan produk atau jasa karena konsumen tidak harus bertemu langsung dengan pihak perusahan untuk memilih produk yang diinginkan. Pemasaran produk yang dipasarkan bersifat online sehingga setiap orang dapat dengan mudah mengakses dimanapun dan kapanpun informasi produk. Selain itu konsumen dapat melihat track record perusahaan dari rating setiap perusahaan.

Cloud computing sebagai suatu model yang mempermudah ketersediaan dan konfigurasi layanan baik berupa perangkat lunak, jaringan, server, media penyimpanan maupun aplikasi. Keberadaan e-commerce yang berbasis cloud computing dapat membantu masyarakat untuk mengakses informasi produk dengan cepat, maka dari itu dibutuhkan sistem e-commerce yang dapat mendukung penjualan dan pemasaran produk perusahaan gypsum untuk dijadikan bahan penulisan usulan dengan judul: "rancang bangun sistem e-commerce marketplace gypsum berbasis cloud computing".

Penelitian [2] membangun sistem informasi penjualan yang memiliki fitur tren penjualan, Laporan tren penjualan digunakan untuk mengetahui lifetime sebuah produk dan menentukan jumlah pemesanan kepada supplier pada periode berikutnya. Informasi tersebut diperlukan sebagai input bagi strategi marketing dalam menjaga relasi dengan pelanggan atau supplier utama. Penelitian [3] membantu perusahaan dalam permasalahan pengelolaan e-commerce dan kekurangan sumber daya. Permasalahan tersebut diselesaikan dengan penerapan cloud computing didalam pengembangan e-commerce dikarenakan cloud computing memiliki 3 layanan sebagai sumber daya yaitu laaS (Infrastructure as a Service), PaaS (Platform as a Service), da SaaS (Software as a Service). Model penggunaan cloud computing dapat digunakan untuk penyimpanan data yang terintegrasi.Penelitian [4] membahas pembuatan sistem informasi teknologi cloud computing menggunakan layanan Software As A Services (SaaS) yang berbasis web. hasil penelitian mengunakan metode likert menunjukkan lebih dari $50 \%$ setuju dengan penggunaan sistem ini.

Sistem e-commerce marketplace gypsum berbasis cloud computing diterapkan untuk mempermudah transaksi jual beli, sedangkan hal yang membedakan penelitian ini dengan sebelumnya terletak pada fitur pelayanan. Fitur pelayanan digunakan untuk memberikan pelayanan tambahan kepada pembeli jika pembeli memiliki keluhan, pelayanan yang diberikan berupa pemasangan gypsum, service pemasangan, dan pengecetan.

\section{Metodologi Penelitian}

Sistem e-commerce marketplace gypsum merupakan sistem informasi dengan penarapan marketplace dimana adanya banyak pembeli dan banyak penjual yang bertemu di satu sistem platform. Sistem e-commerce marketplace dijalankan dari smartphone dan pc melalui web browser [5].

Alur penelitian rancang bangun sistem e-commerce marketplace gypsum berbasis cloud computing meliputi mendefinisikan masalah, pengumpulan data, perancangan alur sistem perancangan dan pembuatan database, implementasi rancangan, pengujian aplikasi, dan pengambilan keputusan.

Metode pengumpulan data dilakukan melalui metode observasi dan studi literatur [6], metode observasi, yaitu mengumpulkan data dengan melakukan pengamatan dan dokumentasi

Rancang Bangun Sistem E-Commerce Marketplace Gypsum Berbasis Cloud Computing 38 (I Gusti Ngurah Wira Dharma) 
langsung terhadap hal yang berkaitan dengan jual beli gypsum. Metode studi literatur yaitu menganalisa data yang diperoleh berdasarkan buku - buku referensi dan jurnal yang digunakan, sehingga diperoleh suatu kesimpulan yang lebih terarah pada pokok pembahasan.

\subsection{Gambaran Umum Sistem}

Sistem e-commerce marketplace gypsum berbasis cloud computing secara umum dapat diilustrasikan seperti pada Gambar 1.

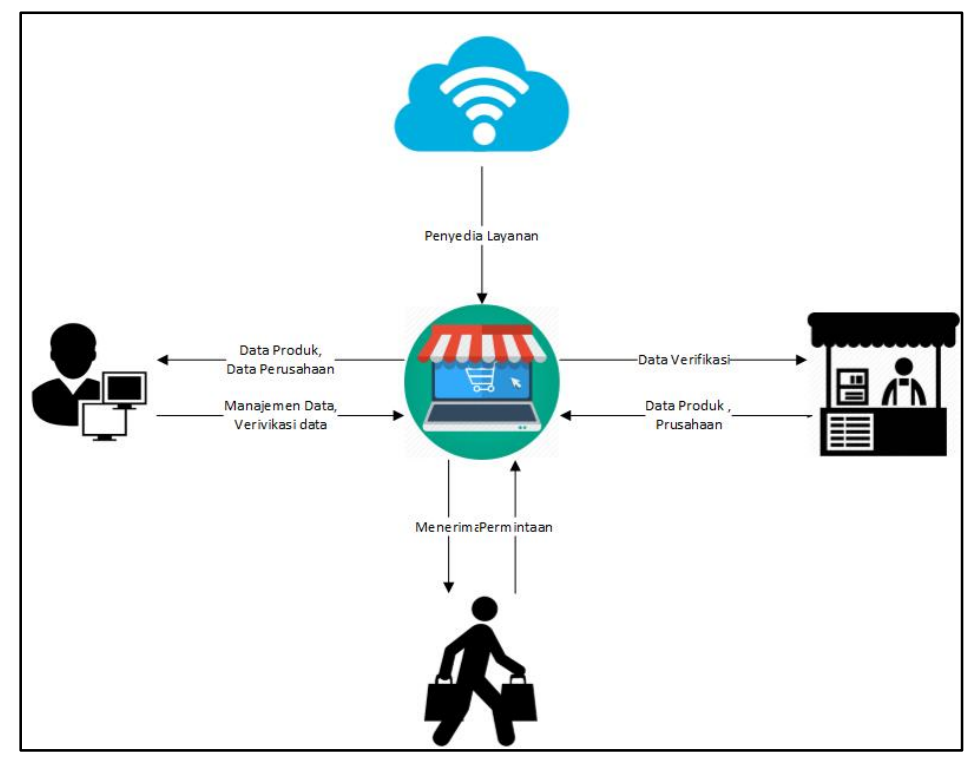

Gambar 1. Gambaran Umum Sistem E-Commerce Marketplace

Gambar 1 sistem e-commerce marketplace gypsum berbasis cloud computing memiliki beberapa fitur yaitu: fitur booking pelayanan, fitur order yang akan memberikan kemudahan dalam melakukan kerjasama terhadap pihak konsumen karena pada fitur ini memiliki kesepakatan pengerjaan proyek, fitur rating atau penilaian kepada pihak perusahaan yang dapat dijadikan sebagai track record terhadap kinerja perusahaan. Sistem e-commerce marketplace gypsum sendiri berbasiskan cloud sehingga database yang terdapat di sistem terintegrasi secara keseluruhan guna mempermudah pengawasan transaksi yang berjalan.

\section{$2.2 \quad$ Use Case}




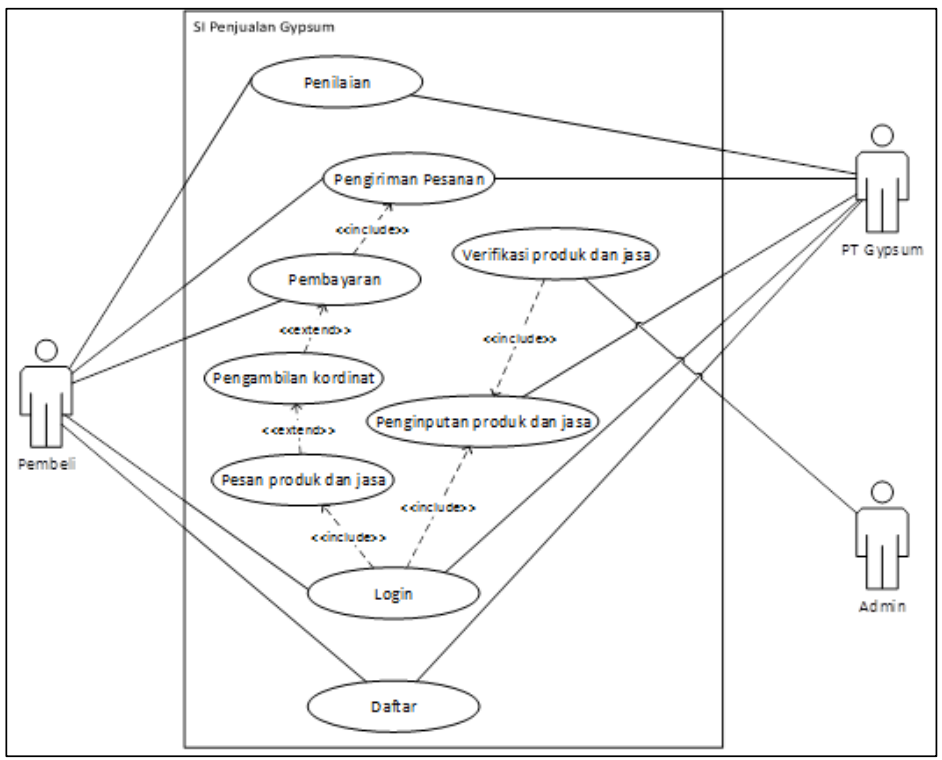

Gambar 2 Use Case

Gambar 2 merupakan gambaran dari use case diagram sistem informasi penjualan gypsum yang terdiri dari daftar, login, pemilihan produk, pengambilan kordinat, penginputan produk dan jasa, verifikasi produk jasa, pembayaran, pengiriman pesanan, dan penilaian. Use case pesan produk dapat dijalankan oleh aktor pembeli dengan menjalankan use case login terlebih dahulu, setelah itu aktor pembeli dapat menjalankan use case pesan produk dan jasa. Aktor pembeli yang menjalankan use case pesan produk dan jasa selanjutnya harus memasukan titik kordinat pengiriman serta melakukan pembayaran. Use case pengiriman pesanan dijalankan jika use case pembayaran sudah dijalankan oleh aktor pembeli. Use case penginputan produk dan jasa dapat dijalankan jika use case login dan use case verifikasi produk dan jasa sudah dijalan kan oleh aktor admin. Use case penilaian dapat dijalan kan oleh aktor pembeli dan aktor PT gypsum, fungsi dari use case ini yaitu untuk pemberian nilai atas pekerjaan yang dikerjakan oleh PT gypsum.

\section{Kajian Pustaka}

\subsection{E-Commerce}

Electronic Commerce (e-commerce) adalah proses pembelian, penjualan atau pertukaran produk, jasa dan informasi melalui jaringan komputer. e-commerce merupakan bagian dari e-business, di mana cakupan e-business lebih luas, tidak hanya sekedar perniagaan tetapi mencakup juga pengkolaborasian mitra bisnis, pelayanan nasabah, lowongan pekerjaan.

\subsection{Cloud Computing}

Cloud computing merupakan layanan komputasi teknologi informasi yang mencakup layanan hardware, software dan aplikasi yang dapat diperoleh melalui internet. Layanan tersebut harus dapat disesuaikan dengan kebutuhan pengguna dan biaya penggunaan layanan dikenakan sesuai jumlah sumber daya yang telah digunakan pengguna menggunakan basis per bulan atau per menit. Layanan cloud computing memiliki 3 model layanan yang dapat digunaan sesuai kebutuhan, 3 layanan tersebut antara lain laaS, PaaS dan SaaS [7].

\subsection{Google Maps API}

Google Maps adalah sebuah perangkat lunak dalam Internet yang berisi peta atas sebuah wilayah atau lokasi. Peta tersebut menunjukkan gambaran sebagaimana yang sering kita jumpai dalam peta konvensional yang dibuat secara cetak baik itu dalam bentuk buku atau juga dalam bentuk pelukisan [8]. Google Maps API merupakan javaScript yang memungkinkan penyesuaian peta dengan konten dan citra untuk ditampilkan dihalaman web. Google Maps API 
memiliki empat jenis peta dasar (peta jalan, satelit, hibrida, dan medan) yang dapat di modifikasi sedemikian rupa.

\subsection{Standart Operational Procedure (SOP)}

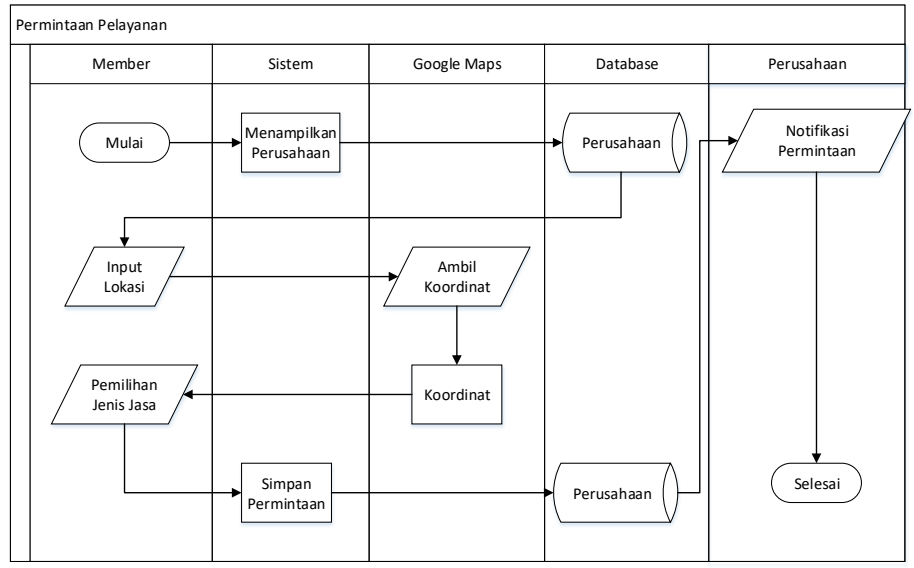

Gambar 3. SOP Permintaan Pelayanan

Gambar 3 merupakan SOP permintaan pelayanan merupakan alur proses permintaan pelayanan dari member ke perusahaan. Member mendapatkan pelayanan berupa pemasangan, service dan pengiriman barang oleh perusahaan gypsum yang dipilih oleh member tersebut.

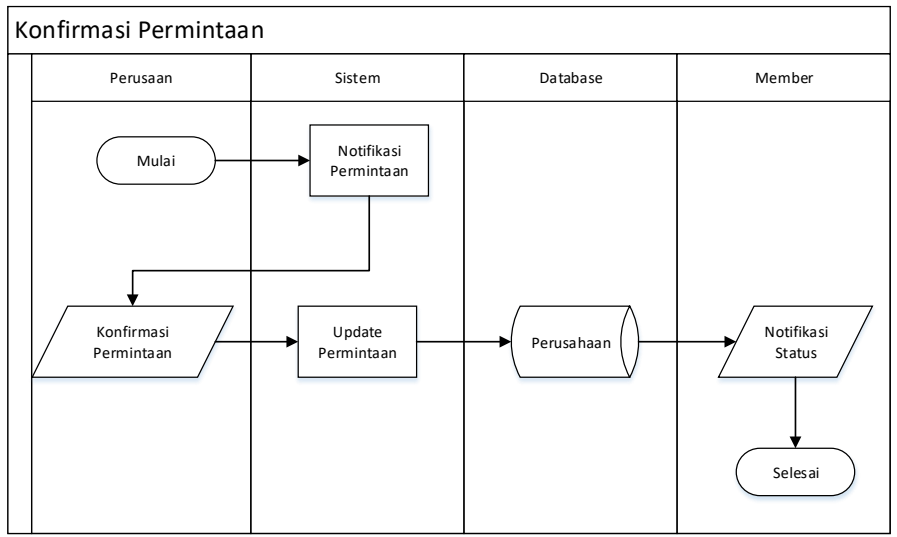

Gambar 4. SOP Permintaan Pelayanan

Gambar 4 merupakan SOP permintaan pelayanan merupakan alur proses permintaan pelayanan dari member ke perusahaan. Member mendapatkan pelayanan berupa pemasangan, service dan pengiriman barang oleh perusahaan gypsum yang dipilih oleh member tersebut. 


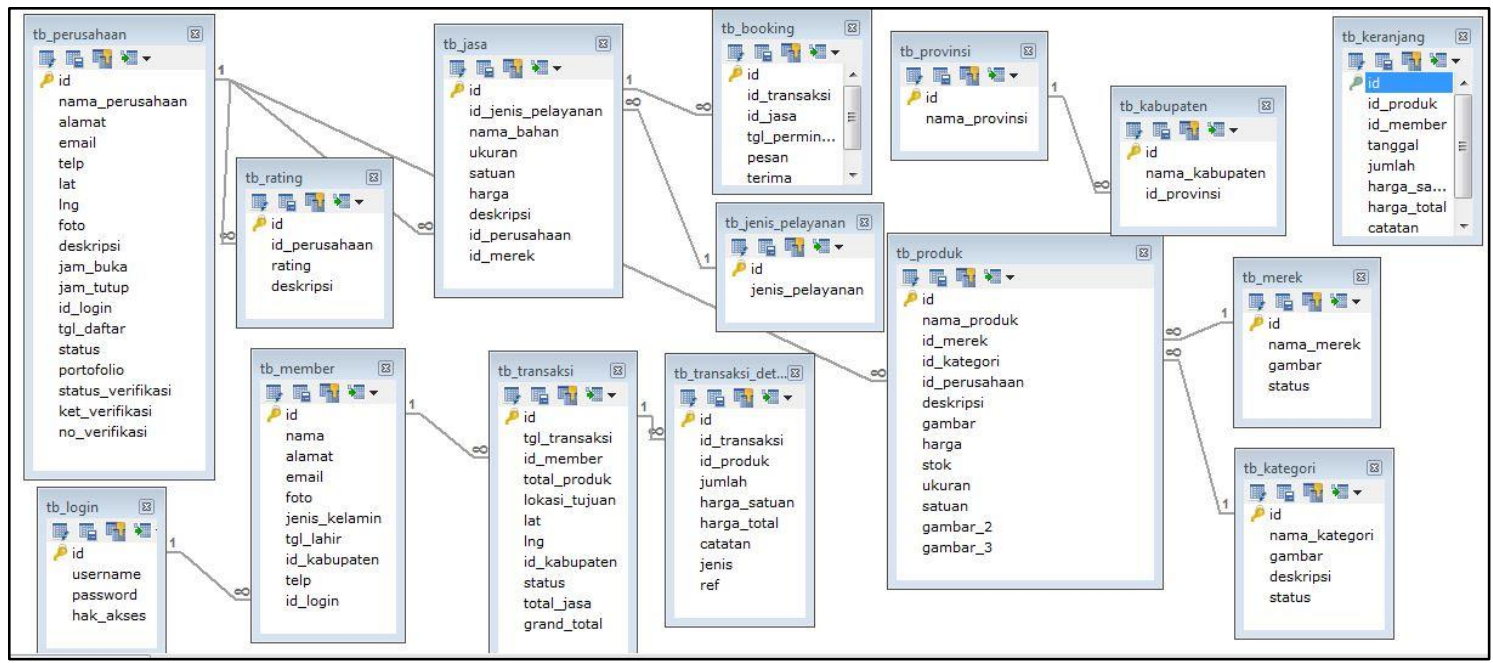

Gambar 5. Desain Database

Gambar 5 merupakan desain database dimana tabel yang dibuat terdiri dari tabel perusahaan, tabel rating, tabel jasa, tabel booking, tabel provinsi, tabel kabupaten, tabel keranjang, tabel login, tabel member, tabel transaksi, tabel detail transaksi, tabel produk tabel merek, dan tabel kategori.

\subsection{Diagram Konteks dan DFD Level 0}

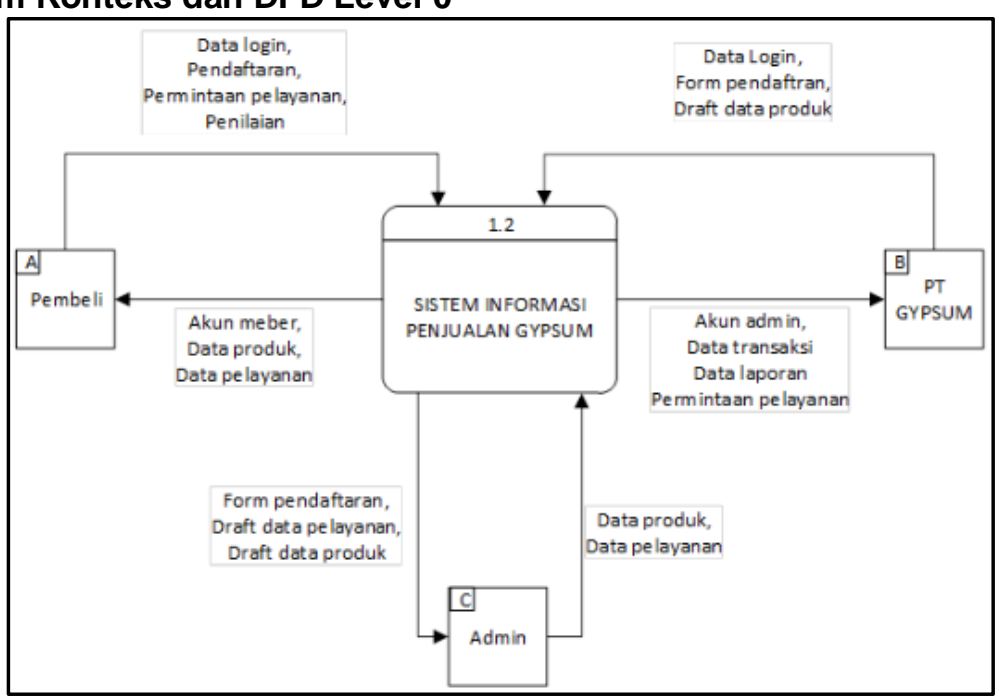

Gambar 6. Desain Diagram Konteks

Gambar 6 merupakan diagram konteks, yang terdiri dari tiga entitas yaitu pembeli, perusahaan gypsum dan admin. Ketiga entitas tersebut saling berelasi dalam proses manajemen data yang bermuara pada sistem. 


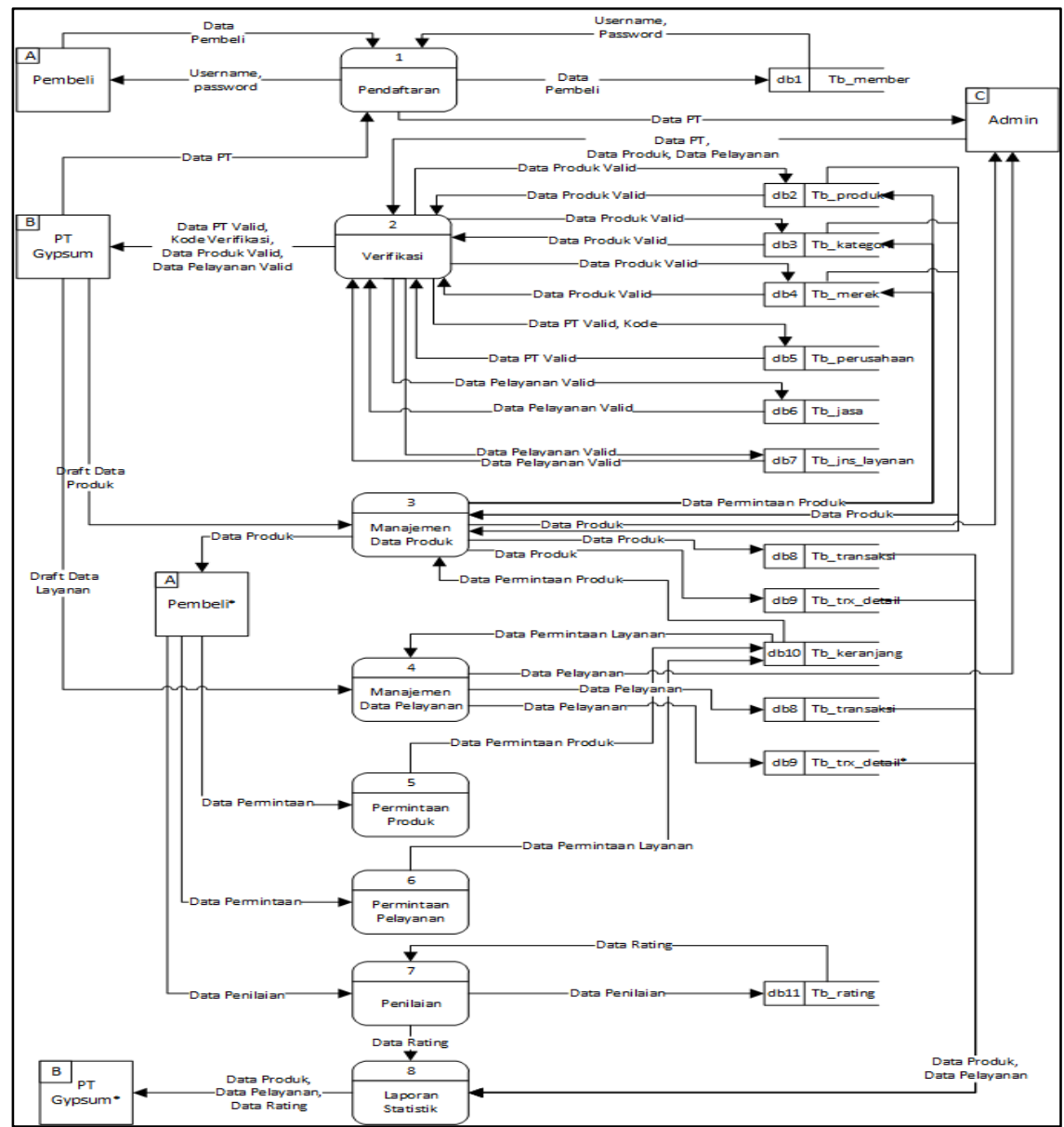

Gambar 7. Desain DFD Level 0

Gambar 7 merupakan diagram konteks, yang terdiri dari proses pendaftaran, verifikasi, manajemen produk, manajemen pelayanan, permintaan produk, permintaan pelayanan, penilaian dan pelaporan.

\section{Hasil dan Pembahasan}

Hasil dan pembahasan memaparkan hasil dari sistem e-commerce marketplace gypsum. Hasil yang diperoleh yaitu pelaporan dari transaksi saat adanya pembelian dan penjualan produk atau jasa. Gambar 8 menunjukkan hasil dari pelaporan pembelian dan penjualan dari salah satu PT gypsum.

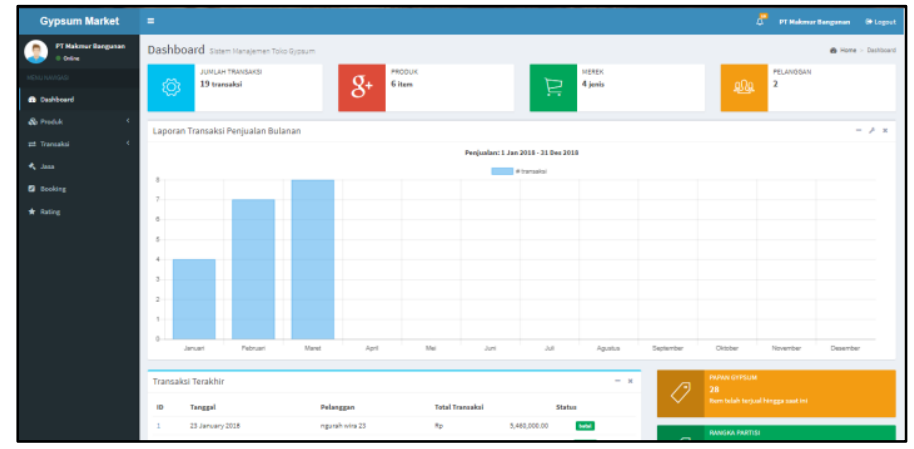

Gambar 8. Dashboard Sistem

Gambar 8 menampilkan hasil pelaporan keseluruhan transaksi dari semua perusahaan gypsum dalam rentang waktu satu tahun. 


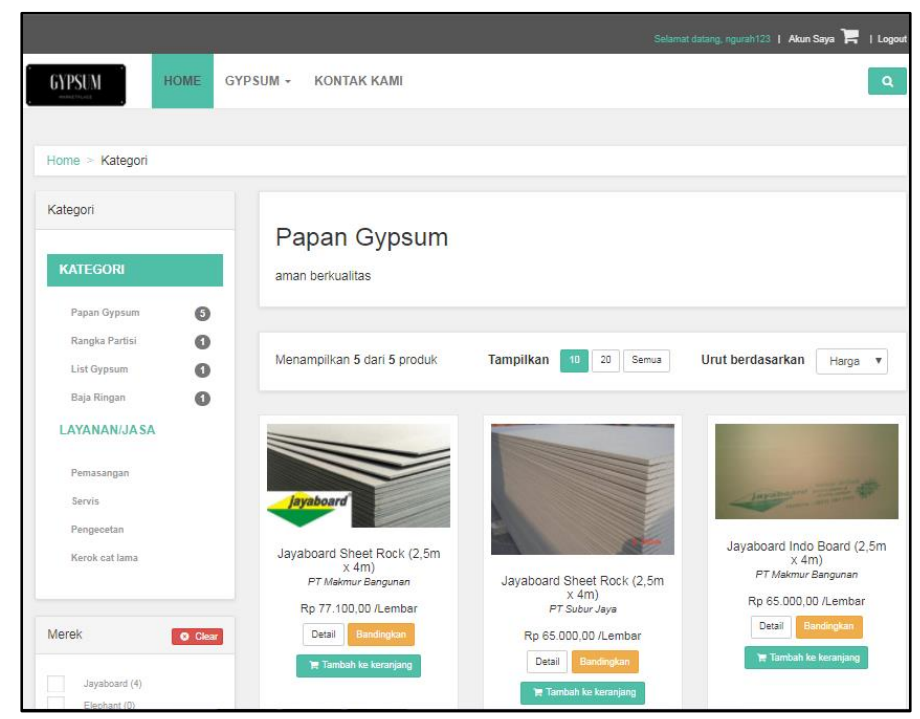

Gambar 9. Halaman Produk

Gambar 9 Halaman produk merupakan halaman yang memiliki fungsi untuk menampilkan produk dan jasa Fitur yang terdapat pada halaman ini yaitu fitur bar untuk memudahkan pembeli memilih produk berdasarkan kategori dan merek dari produk tersebut, selain itu pembeli juga dapat memilih jasa yang diinginkan.

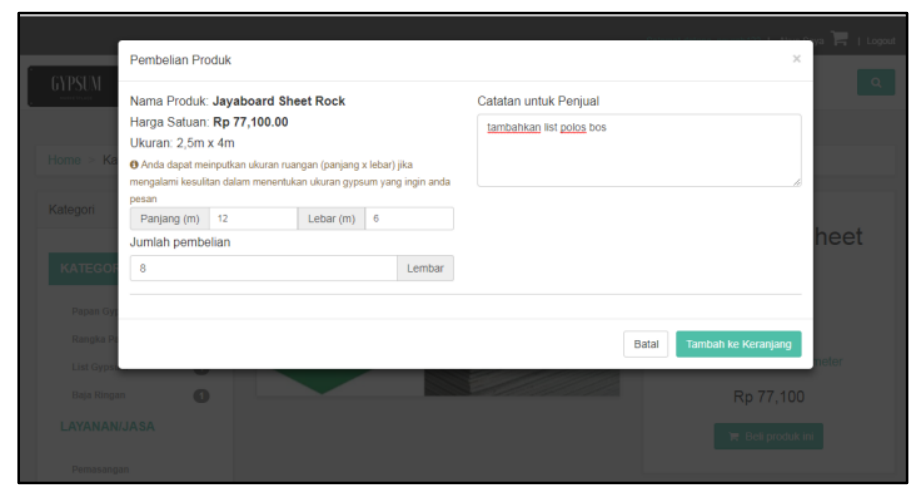

Gambar 10. Halaman Pembelian Produk

Gambar 10 merupakan halaman pembelian produk memiliki fitur untuk melakukan pemesanan produk dimana pembeli mamasukkan panjang dan lebar ruangan, selanjutnya sistem merekomendasi jumlah gypsum yang harus dibeli, jika terdapat permintaan khusus pembeli dapat menuliskan di kolom catatan untuk penjual. 


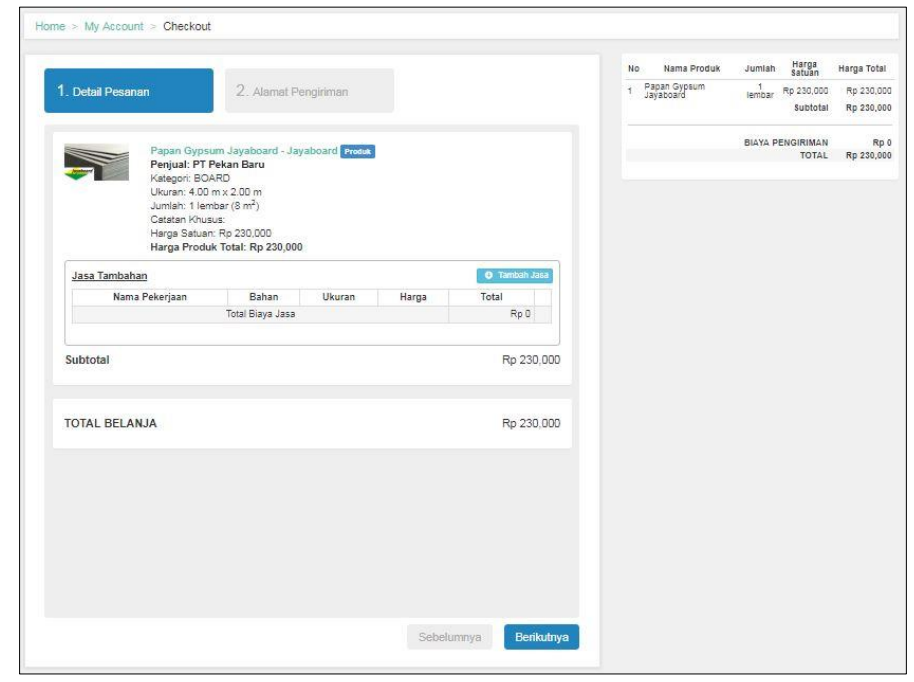

Gambar 11. Halaman Checkout 'detail pesanan'

Gambar 11 merupakan halaman checkout 'detail pesanan' memiliki fitur untuk menampilkan total harga keseluruhan produk yang dibeli serta pembeli dapat menambahkan jasa produk.

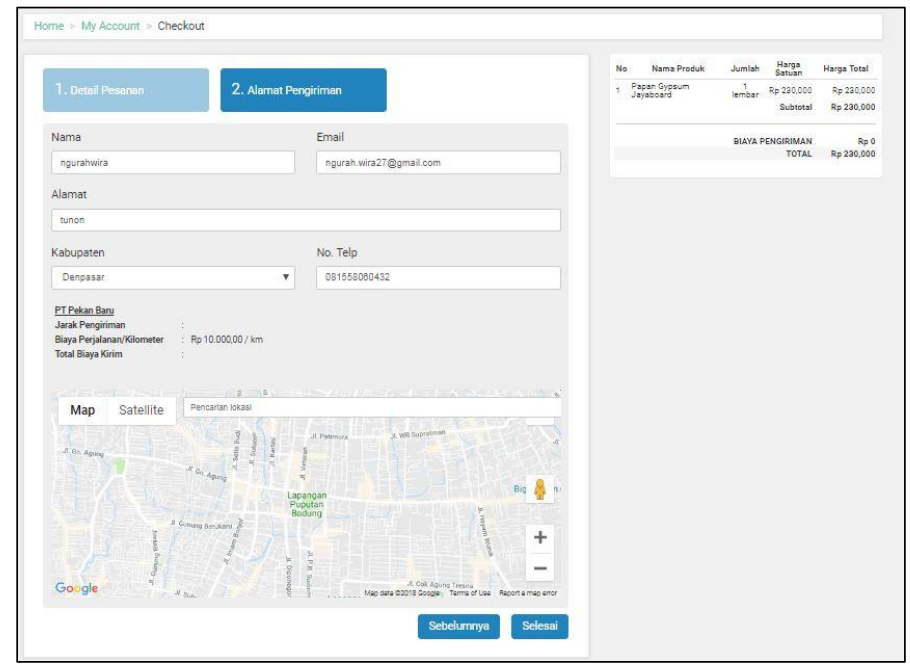

Gambar 12. Halaman Checkout 'detail alamat pengiriman'

Gambar 12 adalah Halaman checkout 'detail alamat pengiriman' memiliki fitur untuk menampilkan total harga keseluruhan produk yang dibeli serta pembeli dapat menambahkan alamat pengiriman yang lebih akurat.

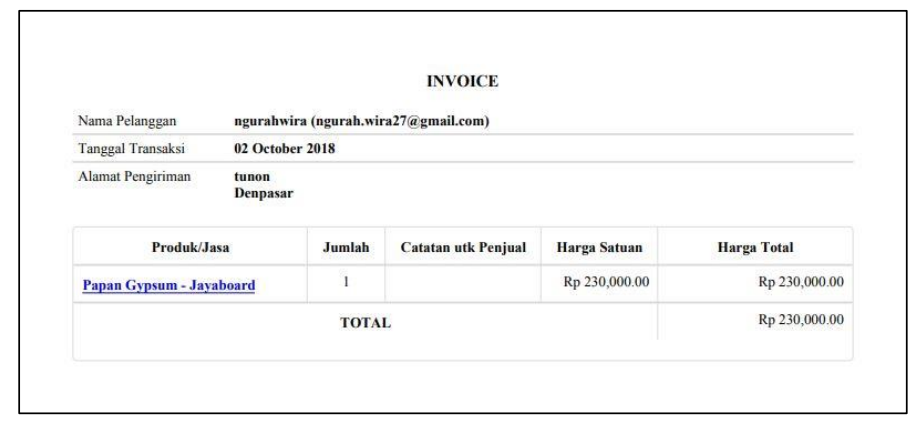

Gambar 13. Halaman Invoice 
Gambar 13 merupakan halaman invoice menampilkan hasil data pesanan nama pelanggan, tanggal transaksi, alamat tujuan, produk yang dibeli serta jasa tambahan yang di pesan oleh pembeli.

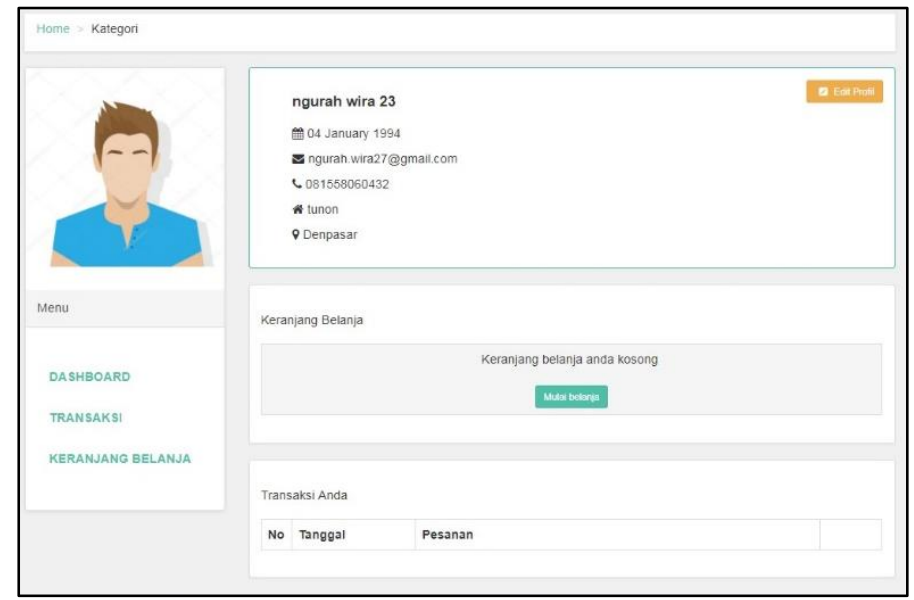

Gambar 13. Halaman Invoce

Gambar 13 merupakan halaman dashboard pembeli, halaman yang memiliki fitur untuk melihat histori transaksi, histori keranjang belanja serta menampilkan data diri pembeli.

Analisis hasil pengujian penggunaan aplikasi oleh user, berdasarkan aspek tampilan antarmuka sistem dan aspek kesesuaian proses dan fitur. Pengujian aplikasi oleh user dilakukan dengan metode penyebaran kuisioner kepada 20 responden yang terdiri dari pembeli dan pihak perusahaan.

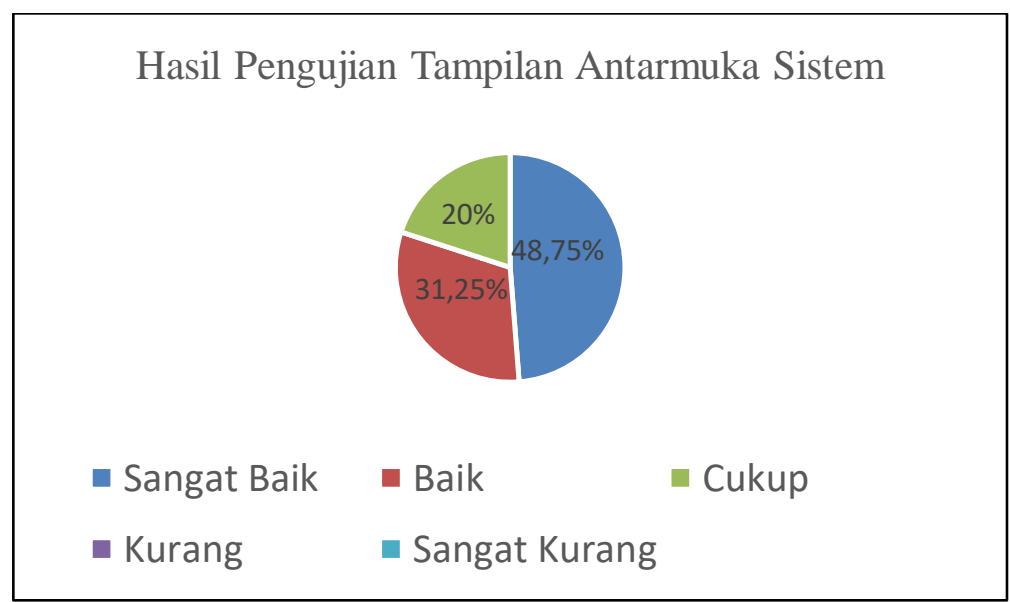

Gambar 14. Grafik Hasil Pengujian Antarmuka Sistem

Gambar 14 hasil pengujian tampilan antarmuka sistem didapatkan sebesar 48,5\% dari total responden memberikan jawaban sangat baik, 31,25\% memberikan jawaban baik dan $20 \%$ dari total responden memberikan jawaban cukup. Berikut ini merupakan hasil pengujian uang digambarkan dengan grafik terdapat pada Gambar 14. 


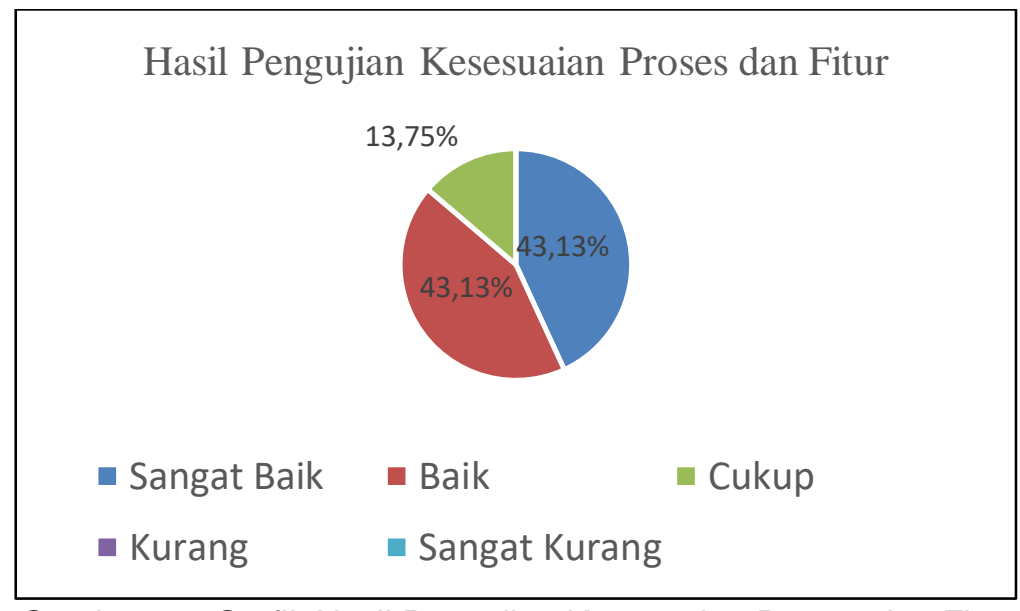

Gambar 15. Grafik Hasil Pengujian Kesesuaian Proses dan Fitur

Gambar 15 pengujian kesesuaian proses dan fitur didapatkan hasil sebesar $43,13 \%$ dari total responden memberikan jawaban sangat baik, $43.13 \%$ memberikan jawaban baik, $13.75 \%$ memberikan jawaban cukup.

\section{Kesimpulan}

Simpulan sistem e-commerce marketplace gypsum menerapkan teknologi cloud computing dan responsive web, sehingga dapat diakses dari perangkat mana saja dengan terhubung ke internet dan tampilan serta manajemen data yang mudah dipahami. Seluruh data dan alur transaksi dapat terpadu, termonitoring, dan terkontrol. Penjualan gypsum dengan penerapan e-commerce marketplace berbasis cloud computing dapat membantu perusahaan gypsum untuk menjual produk dari mana saja, mengurangi biaya pemasaran, serta respon dari setiap transaksi lebih cepat. Sistem e-commerce marketplace gypsum berbasis cloud computing berjalan dengan baik dari aspek tampilan antar muka sistem dan kesesuaian fitur. Pengujian kepada 20 responden memberikan penilaian sangat baik dan baik sebesar $80 \%$ dari aspek antarmuka, sedangkan dari aspek kesesuaian fitur responden memberikan penilaian sangat baik dan baik sebesar $86,26 \%$.

\section{Daftar Pustaka}

[1] M. E-commerce, "Upaya Pengembangan Usaha Kecil Dan Menengah (Ukm) Dengan Memanfaatkan E-Commerce," vol. 2, no. 1, pp. 159-168, 2010.

[2] C. Bagi, U. Kecil, D. A. N. Menengah, and D. I. Indonesia, "RANCANG BANGUN SISTEM INFORMASI PENJUALAN BERBASIS CLOUD BAGI USAHA KECIL DAN MENENGAH DI INDONESIA (Studi Kasus: Toko 'Toko Besar')," no. 1, 2011.

[3] L. Rukhsara, F. Aklam, T. Nawer, N. S. Chauhan, and M. N. Islam, "E-commerce Applications in Context of Bangladesh," pp. 117-121, 2016.

[4] P. S. Saputra, I. M. Sukarsa, and I. P. A. Bayupati, "Sistem Informasi Monitoring Perkembangan Anak di Sekolah Taman Kanak - kanak Berbasis Cloud," vol. 8, no. 2, pp. 112-123, 2017.

[5] E. Triandini, A. Djunaidy, and D. Siahaan, "Factors Influencing E-Commerce Adoption by SMES Indonesia: A Conceptual Model," vol. 4, no. 3, pp. 301-311, 2013.

[6] J. Teknologi, I. Universitas, and C. Computing, "Aplikasi Back End Manajemen Restoran Berbasis," vol. 2, no. 1, pp. 98-105, 2014.

[7] P. Mell, T. Grance, and T. Grance, "The NIST Definition of Cloud Computing Recommendations of the National Institute of Standards and Technology."

[8] I. K. Agus and A. Sudiartha, "Sistem Informasi Geografis Pura Di Pulau Bali Pada Platform Blackberry," vol. 1, no. 2, pp. 1-10, 2013. 
MERPATI VOL. 7, NO. 1 APRIL 2019

ISSN: 2252-3006 